\title{
School Bullying: The Need for Recognizing this Phenomenon in Albania
}

\author{
Dr. Ledia Kashahu (Xhelilaj) \\ "Aleksandër Moisiu" University, Durrës/ Faculty of Education, Pedagogy Department, Lecturer \\ kashahuledia@yahoo.com
}

\author{
Doi:10.5901/ajis.2014.v3n3p542
}

\section{Abstract}

\begin{abstract}
The lack of teachers' attention and communication and Albanian parents with children and the youth have created the proper ground that in schools to happen constantly serious acts of violence. Recently they have become very worrying because of their high frequency and have created uncertainties. According to this reality some studies are done which testify the high level of violence through bullying behaviour which are qualified by world literature as violent forms. This article aims at bringing a theoretical contribution on bullying phenomenon and to highlight the immediate necessity for scientific knowledge of this phenomenon in Albania. The author aims at clarifying from the theoretical view the characteristic that make behaviour to be qualified as a bullying one. Furthermore, through the description of the phenomenon based on the findings of world literature, it is made clear in what conditions the behaviour happens, which are included and their attitudes. In this commentary the readers through scientific arguments based on a series of studies, understand the immediate consequences that the inclusion of the children has in bullying acts as well as those long-term which accomplish the individual throughout his life as an adult. Furthermore, the author treats the importance that the attitudes of the teachers and of the parents have in the treatment of the phenomenon. In the end the author identifies some measures that must be taken from the school as well as from the family to treat the phenomenon successfully. In her conclusions the author emphasizes that for the changing of the situation the work firstly have to be started with the awareness campaigns for the children and parents. The same of importance she values the support in the constant education of the staff pedagogy, who necessarily have to be included in the modules of training which train not only the phenomenon theoretically to understand its importance but even that helps with concrete strategies in the confront with it. Moreover the author values that it is necessary the interference in the curricula starting from the curricula of the $9^{\text {th }}$ grade school pupils and then continuing with the interference of the curricula in the faculties of education which prepare the future teachers.
\end{abstract}

Keywords: bullying in schools, bullying phenomenon, bullying victims, bystander, bully.

\section{Introduction}

Insecurity has hit Albanian schools due to the violent incidents that have followed one another. Actually, these events have caused a large concern among the public and political actors as well. For instance, on February $29^{\text {th }} 2014$, the Minister of Sports and Education, Mrs. Nikolla declared for the public that all the precautions needed will be taken in order to prevent violent actions inside our schools. If we analyze the origins of these painful stories, we will deduce that the conflicts among students did not develop promptly, but these conflicts were a collection of bullying actions. Following this logic I would like to refer to the episode occurred on December 13th, 2013 in "Kolin Gjoka" Professional High School in Lezha, where an 18-year-old student with the initials A. Gj. was seriously wounded with a knife by another student after a series of continuous conflicts between them. (Vizion Plus 12.13 .13$)^{1}$. In the same way, continuous verbal conflicts between a 16-year-old and a 15-year-old student caused the death of the youngest, who was shot with a weapon by his schoolmate in "Beqir Çela" High School in Durrës, on December $16^{\text {th }}$ 2013. (Shqiptarja.com)2.

The lack of attention from parents and teachers towards bullying actions has resulted in negligence and also in problems not treated in due time. This is one of the main reasons why these conducts have deteriorated in criminal offenses like injuries caused by solid objects, weapons, or even murders. Unfortunately, in some occasions, the extreme violence inside the classrooms and school yards has caused suffering not only for the victims, but it has also resulted in anxiety and insecurity for the rest of the students and their parents.

The 2006 World Report Against Children Violence had identified four main forms of violence: a) physical and psychological punishment; b) bullying; c) sexual violence and the one based on gender; d) external violence (effects of

\footnotetext{
${ }^{1}$ http://vizionplus.al/lezhe-plagoset-me-thike-18-vjecari/

2 http://ëëë.shqiptarja.com/Aktualitet/2731/durr-svrasja-n--or-n-e-m-simit-15-vje-ari-m--shau-nga-motra-189837.html
} 
gangs, conflicts and wars). So it is obvious that bullying is referred to as a form of violence. It is a well-known phenomenon that is present not only in our country, but is also this disturbing and acute in the rest of the world (Cook, Williams, Guerra, \& Kim, 2009; Kanetsuna \& Smith, 2002). This is the reason why this phenomenon has been on the focus of many studies in the last three decades (Dussich\& Maekoya, 2007).

Even though it is a worldwide phenomenon, its prevalence in Albania is larger than in other countries. Different worldwide studies have proved that the prevalence of this phenomenon varies by the way it is measured from $10 \%$ to 30\% (Nansel et al., 2001; Solberg \& Olweus, 2003). The printed press in Albania constantly shows attention about the study reports that are related to violence and conflict. So, for example, "Zëri i Popullit" newspaper has published an article on a study with a sample of 1435 students, conducted by Save the Children and Conflict Resolution and Reconciliation of Disputes Foundation. This study proves that $28 \%$ of the students have been part of serious conflicts in schools and $42 \%$ of them do not feel safe in their classrooms.

Researchers like Tamo and Karaj (2006) have also found similar prevalence. Their studies show that $48 \%$ of the interviewed children admit to be physically violated in schools from their schoolmates. Another explorative study conducted in 2012 from CDE with a found from the Agency for the Support of the Civil Society, has discovered that $50 \%$ of the children have faced bullying in schools, and more disturbing is the fact that only $5 \%$ of them have reported such a violence to teachers and $29 \%$ of them have discussed these problems with their parents. According to these features we understand that there are a large number of children that do not report bullying actions. This is another appeal in order to make a serious effort to further explain this phenomenon not only for the pedagogic staffs, but also for the children themselves and their parents.

\section{What is bullying?}

According to Olweus (1998), bullying is a combined behavior. He explains that bullying is a conduct that contains in itself threat, intimidation, harassment, isolation, swearing and slander that aim denigration. According to him, the act of bullying involves two or more people that usually find themselves in these roles:

- The Bully: the one that takes the initiative to act violently towards others

- The Victim: the person that suffers from the acts of violence

- Te Bully's assistant: is the person that encourages the bully even though he does not have a main role in the conflict.

- The victim's helper: the person or people that actively interfere to demand the protection of the victim by interrupting the act of violence, or even by commiserating with the victim when they cannot stop bullying.

- The Bystanders: is the person that is present in the conflict and does nothing to stop the violence and does not take sides (Olweus 1973, 1978)

The typical factors that define bullying are: 1) the goal; 2) the intensity, permanency; 3) the asymmetry between power and strength. When it comes to the goal, the bully uses many different forms to threaten, harass and isolate the victim. (Olweus, 1993). According to the researcher Ericson (2001), bullying can be manifested in three forms: a) physical bullying (that involves hitting, kicking, pushing, damaging and stealing of personal possessions); b) verbal ( as mockery, molestation, nicknames, intimidation and threats); c)psychological (like defamation, manipulation of social relationships, the aim to achieve social expulsion, torturing and public embarrassment). Whereas according to the researcher Smith (2001) there are different types of bullying:

- Physical bullying- hitting, kicking, pushing, damaging of personal possessions

- Verbal bullying- molestation, mockery, threats

- Social Expulsion- systematic expulsion of somebody part of a social group (for instance: "you cannot play with us anymore")

- Indirect and rational- defamation, asking others not to play with somebody anymore.

- Cyber Bullying- the attack achieved through messages, e-mails and websites on bullying (Smith 2001, pg. 43).

No matter how bullying forms are listed, one thing is clear: the bully acts physically, verbally and psychologically with the aim of harming the victim and when he finally achieves the goal, which is to make the victim suffer, the bully experiences pleasure. In order for a behavior to be classified as bullying it should be characterized by the intensity and permanency. This means that bullying acts do not happen only once, but is a conduct repeated within weeks, months or even years. However, this doesn't mean that a single serious act of violence cannot be classified as bullying. On the other hand, there is an asymmetry in the power and strength ratio between the bully and the victim. The bully is usually an older child, physically stronger and more powerful from the social point of view. An individual is judged as a bullying 
victim if he/she is systematically exposed, in the aspect of time, to negative actions taken by another individual or a group of people (Olweus, 1993).

Studies on bullying have shown that this kind of behavior can be visible (direct) or invisible (indirect). To be more concrete, in the category of direct bullying actions, that are more visible, we include actions that are more visible and that are related to physical and verbal violence, like hitting, kicking, damaging or theft of personal possessions and calling the victim with pejorative nicknames. When it comes to indirect bullying actions we include the forms of psychological bullying with such conducts as social expulsion, social manipulation, defamation and even cyber bullying that include threat or intimidation, denigration or public embarrassment, that in most of the cases is achieved by electronic gadgets like computers or mobiles (Espelage, \& Swearer, 2004; Olweus 1993; Rigby, 2002).

\section{Short-term and long-term effects on children}

Short-term and long-term effects related to bullying behavior issues have been positioned on the focus of many researchers during the last decade. This due to the fact that exactly in the last years the national and international public opinion was continuously disturbed by these acts of violence happened in schools, and for this reason the social sensibility concerning bullying phenomenon and its effects has grown. Continuous studies have concluded that children that are victims and bullies as well show difficulty in the academic field (Fonagy, Twemlow, Vernberg, Sako, dhe Little, 2005; Hammig \& Jozkowski, 2013; Jensen \& Dieterich 2007; Rigby 2007; Støm, Thoresen, Wentzel-Larsen, \& Dyb, 2013), psychological problems like anxiety, low self-esteem, suicidal thoughts ((Jensen \& Dieterich 2007; Rigby 2007; Thorbes, 2003), problems related to antisocial relationships like violence, drug use, (Farrington, \& Ttofi, 2011; Hong 2009; Jensen \& Dieterich 2007; Vieno, Gini \& Santinello, 2011), problems in their social relationships towards others (Graham, Bellmore , \& Juvonen , 2003; Ladd , 2003; Nansel et al , 2001), even preserving the distance from teachers (Bierman, 2011; Shinn \& Kim, 2008) and parents (Fishman et al. 2002), and this contingent of individuals is not rarely involved in criminal offences as well ((Hay, 2010; Olweus, 1993).

A research was made lately in Oslo, Norway, with a sample of 7343 teenagers of the age of 15-16 years old, where besides other behaviors bullying was also measured. The sample was divided into two groups: students that are worried about bullying and students that do not worry about it. Researchers concluded that the students that have been victims of bullying actions achieve poor academic results in comparison to the other group of students (Støm, Thoresen, Wentzel-Larsen, \& Dyb, 2013). In the same way, the research made by Hamming \& Jozkowski (2013), with a sample of 15353 American teenagers, where they studied the relation between the academic results and violence victimization, proved that the higher the threat from different forms of violence, the lower the teenagers' academic achievements. It was found that victimization explains $4.4 \%$ of the poor academic results in female teenagers and $6.6 \%$ in male teenagers.

Moreover, in the Bauman and Del Rio research (2006) was discovered that the presence of bullying actions in schools causes in students psycho-somatic disorders that bring non-desired changes even in physical health. This inadequate health condition influences in the decline of academic results. This because the student's attention is focused on self-defense rather than on learning. Siris and Osterman (2004) have come up with the same conclusion. They also see the security of a child related to cognitive processes. Moreover, Thorbes (2003) in his research provides arguments that besides the poor academic results, individuals that have experienced victimization because of bullying, also show unstable health condition, unflattering appearance, eating disorders, overloaded anxiety that may lead to depression as well as suicidal thoughts.

It has been discovered since 1993 from the researcher Dan Olweus (1993) that the consequences of bullying are not only of a short-term, but also if children are involved in bullying actions they will face their consequences even in the future, in their adult life. Olweus discovered that $60 \%$ of the individuals that have been part of chronic bullying over the $6^{\text {th }}$ and $9^{\text {th }}$ grade were involved in criminal activities by the time they were 24 years old. Some years later 960 college students submitted to a research. They were asked in the first place to report if they had been involved in bully actions in the last two years of high-school. The researchers evaluated the students' opinion about crime and criminal offenses and it was discovered that having been a bully or a victim could not only foretell criminal thoughts but criminal activities as well (Hey, 2010). In another long-term research was discovered that the children that were involved in bully actions at the age of 14 showed to become too aggressive and violent later at the age of 15-18 years of age. When they reached the 27-32 years of age, they admitted that they were regular drug users, and at the age of 48 they had an unsuccessful life (Farrington, \& Ttofi, 2011).

The research conducted in Italy with 13-year-old children (Vieno, Gini \& Santinello, 2011) found that there is a positive relationship between smoking, drinking alcohol and the involvement of teens in bullying actions. Whereas researchers like Farrington, \& Tofi, (2011) found that $10.4 \%$ of the marihuana users in secondary schools are bullies and 
$6.1 \%$ of them are victims. When it comes to high-school users of marihuana, $31.7 \%$ of them are bullies and $29.2 \%$ of them are victims. According to Fishman and his colleagues (2002) victims don't have close friends and other friends, and even their relationship towards teachers is distant. Moreover these children have a cold and distant relationship even with their parents and they do not ask for their support.

In Albania there are very few researches on bullying, because even though it is a present phenomenon in Albanian schools, little is known from the teachers (Kashahu \& Karaj, 2014 press). However, bullying has recently attracted the researchers' attention. We have to emphasize the fact that these researches are mainly of explorative nature. Concretely, in the research conducted by Kashahu and Karaj (2014) over the perception and approach of the teachers and headmasters on bullying phenomenon, they discovered that after the teachers got shortly acquainted with the basic theoretical knowledge on bullying phenomenon, they were able to judge based on their experience that the negative effects of bullying on children appear in many directions: a) these children experience insecurity and anxiety; b) due to this behavior, they tend to drop school; c) their self-esteem decreases; d) they take lower marks; e) they fall into depression and they even commit suicide; f) they tend to act violently and even commit criminal offenses.

\section{School Role}

Different research findings about the school environment influence on bullying behavior rehabilitation are contradictory (Meyer-Adams \& Conner, 2008; Pellegrini \& Bartini, 2000; Wienke Totura et al., 2008). Thus, for example, on a long-term research conducted by Pellegrini and Bartini (2000), it was discovered that bullying behavior changes while the child grows up and wears on from primary to secondary school. In this phase school environment has less influence. For this reason, researchers suggest further studies in order to deduce the predictive factors that may lead to bullying actions. Whilst in some later researches related to time aspect, it was found that the negative factors of school environment, like monitoring the student's behavior in low levels may lead to a low sense of security, because in these conditions there are more bullying conducts (Meyer-Adams \& Conner, 2008; Wienke Totura et al., 2008).

According to the last years' studies, it was found that bullying identification up to the school level is not an easy task to complete due to the fact that some forms of bullying conducts are invisible. If we refer to Simmons (2002), he states: "covert aggression isn't just about not getting caught; half of it is looking like you'd never mistreat someone in the first place" (p. 23). On the other hand, teachers play a key role in the identification of victimization signs and those of aggression as well. For this reason they have been estimated as determinative factors not only for the detection of bullying phenomenon, but also for the creation of appropriate conditions in order for the students not to remain silent while facing bullying actions (Smith \& Shu, 2000).

According to Yoneyama \& Rigby, even though most of the times bullying happens away from the teachers' attention, there are many cases where the students' behavior make it possible to deduce wether they have been involved in bullying actions or not. A child that most of the time shows a negative conduct in the classroom, has low results or shows a decrease in academic achievement, that doesn't want to be involved in different school activities, skips classes, doesn't obey to the teacher's authority; all of these signs show that something unusual is happening to that child. If the teachers are attentive to supervise these children and their behavior, especially in places not monitored by them, the teachers may find out that the child is involved in bullying problems (Yoneyama \& Rigby, 2006). Fishman and his colleague (2002) think that in schools, unsuccessful children suffer and feel stressed because of this reason. They try to achieve popularity and attention inside their school through bullying conducts towards other children. This Fishman \& colleagues finding (2002) makes us reflect even more about the Yoneyama \& Rigby recommendations (2006).

Despite the fact that teachers are the most accurate identifiers of bullying conducts, the researchers Smith \& Shu (2002) have defined them also as an important factor in its commination, because is the teacher himself the one that creates the appropriate circumstances for the victim not to remain silent. The relationship between the teacher and the students is essential and has a huge influence in the creation of a warm environment inside the classroom and a close relationship between the children (Bierman, 2011). Researchers have found that a warm and close relationship with teachers has negative impacts on class conflicts (Hamre \& Pianta, 2001), whereas a conflictive relationship between teachers and students has favorable impacts on victimization (Shinn \& Kim, 2008). According to some studies, the warmth and affiliation of the teachers towards students serve as a shield for the shy children by protecting them from victimization and poor academic performance, and it also reflects less aggressiveness among children (Troop- Gordon \& Kuntz, 2013; Runions \& Shaw, 2013). But we also shouldn't forget the fact the fact that is the school's responsibility to protect the children from harming factors and especially from bullies. The school staff should be considered responsible for bullying mishandling and for the consequences that may derive from not treating these situations as they should (Kevorkian \& D'Antona 2008). Researchers like Pepler, Smith and Rigby (2004) go beyond, by defining the teacher's 
commitment as the key factor for the violence interruption.

From the different researches conducted by Kashahu and Karaj (2014), it was found that a considerable part of the teachers perceive bullying actions as a normal behavior related to children growth and development. But researchers like Nansel and his colleagues (2001), who have studies the correlation between bullying conducts and children growth, have concluded that a simliar behavior is not only abnormal, but also harms the children healthy growth. Since the teacher's role is so essential we have to face the real situation created in Albanian schools, where the teachers' and headmasters' theoretical knowledge on the issue would increase their ability to successfully face with this phenomenon (Kashahu and Karaj 2014).

\section{Parental Role}

The family environment, apart from the personal factors of the child, was considered to be an important factor. It can foretell the possibility that a child can or cannot risk to be involved in bullying behaviors (Brendgen et al. 2008). According to Veenstres and his colleagues (2005), there are several personal characteristics of children that make them potential candidates active in bullying behavior like: low academic achievement, unsocial conduct and the refusal of providing explanation when needed, and the level of aggressiveness or even being opened versus being isolated. On the other hand, long-term studies have proved that children raised in aggressive and conflictive environments, where they were also mistreated, face interpersonal and intrapersonal problems, which increase the risk factors of being later involved in bullying behavior (Bowes et al. 2009). Families with a low economic and social status have the tendency to face more conflicts and to abuse their children (Carlson, 2006). Likewise, is to be emphasized that in families which face conflictive dynamics and mistreatment the chance to become empathic is very low (Su, Mrug \&Windle, 2010), and one of the main characteristics of bullies is the lack of empathy (Veenstra, Lindenberg, Oldehinkel, De Winter, Verhulst, \& Ormel, 2005).

Even though the family environment can influence the increase of the risk factors as we mentioned above, the members of the family are the first that can actually deduce if their child has been a victim of violence or if their child is abusing others. Often parents witness their children reluctance to go to school. Attentive parents try to find the reasons that lead their children towards this attitude. The signs that may help to understand if the child is being involved in bullying actions are: change of attitude towards his/her siblings, aggressiveness increase, and secede from friendships he/she has preserved over a long time. In the same way, investigating cases like those where the child comes back home injured, has continuous rips in his/her clothes, or his/her school items are destroyed, or even when he/she has things that don't belong to him/her, are important parental tasks not to be neglected.

In addition, parents should ask for information on bullying in order to be conscious and let know to the children that every form of violence is unfair and punishable. On the other hand, in order to better identify the problem and resolve the conflict, it is important to understand that parents need to communicate with the school if they verify that their children are involved in bullying conducts, with the only purpose of stopping that behavior. Continuous conversations on this topic with the children are necessary, because in many cases they don't confess to be harassed. The main reason is that they feel ashamed or in some cases because they fear to be considered guilty about the situation created.

\section{Conclusions}

The features of this phenomenon's prevalence in Albania are high in comparison to other countries. This is a reason why families, schools and communities should deal with bullying phenomenon more seriously. Introducing the legal predictions, which consider the school as the environment that should protect the children from any kind of violence and should treat carefully any misbehavior that could harm them, to the interests groups is the starting point for our thoughts. The sensitization of the students themselves can be achieved through programs that promote the right of the children, planning a curricular content where the students can learn the values of the moral code based on the respect for others and on the respect for the rule in their classrooms. Understanding emotions and developing empathy through the whole process of teaching and learning, the intermittent highlight in different forms of the importance that creating and preserving friendly relationships with each-other has in an individual's life and also building the skills and habits to manage conflicts and problems resolutions, would help in creating an important basis for the prevention of bullying behaviors.

Based on the above mentioned predictions it is clear that indirect bullying is much more difficult to identify. This is the reason why teachers and parents should stay vigilant in order to understand what is happening to their children. Headmasters can also contribute in the improvement of this situation by planning and organizing topics related to the professional teachers training in dealing successfully with bullying behaviors in inner training sections of the school. 
Experiencing bullying in schools constitutes a negative experience that harms the healthy growth of the child and his quality of life, but it also has its effects on the community. Considering the negative individual influence in the aspect of physical, emotional and social development and also considering the problems that would arise in the future because of them, we face the need to treat this phenomenon more seriously, because it hauls an individual and social cost (Ttofi \& Farrington 2011). Bullying behavior can lead to more serious social and economical issues of the families that have an influence on the community. Chronic bullying can lead to a rising need for more urgent health care, by decreasing the security perceived and the behavior in favor of a community. It has a negative influence in economy. As a result, children do not achieve their full potential and this way they don't fully develop healthy social approaches and behavior (Cowie dhe Jennifer 2008). If professional health care consultants, school staffs intervene we can minimize this cost. Its purpose would be to reduce human suffers, that according to Tofti \& Farrington (2011) has clear scientific proofs that with the professionals' commitment the situation can be managed successfully.

\section{Reference}

Bauman, S., \& Del Rio, A. (2006). Pre-service teachers' responses to bullying scenarios. Comparing physical, verbal, and relational bullying. Journal of Educational Psychology, 98, 219-231.

Su W, Mrug S, Windle M. (2010). Social cognitive and emotional mediators link violence exposure and parental nurturance to adolescent aggression. J Clin Child Adolesc Psychol. 39: 814-824.

Bierman, K. L. (2011). The promise and potential of studying the "invisible hand" of teacher influence on peer relation and student outcomes: A commentary. Journal of Applied Developmental Psychology, 32, 297-303

Bowes., L, Arseneault., L, Maughan, Taylor., A, Caspi., A \& Moffitt., T, E, (2009) School, Neighborhood, and Family Factors Are Associated With Children's Bullying Involvement: A Nationally Representative Longitudinal Study Journal of the American Academy of Child \& Adolescent Psychiatry Volume 48, Issue 5, Pages 545-553

Carlson, K. T. (2006). Poverty and youth violence exposure: Experiences in rural communities. Children and Schools, 28, 87-96.

Cook, C. R., Williams, K. R., Guerra, N., \& Kim, T. (2009). Variability in the prevalence of bullying and victimization: A cross-national and methodological analysis. In S. R. Jimerson, S. M. Swearer, \& D. L. Espelage (Eds.), The international handbook of school

Cowie H, Jennifer D. (2008). New perspectives on bullying. New York: McGraw-Hill

Dussich, J., \& Maekoya, C. (2007). Physical child harm and bullying-related behaviors: A comparative study in Japan, South Africa, and the United States. International Journal of Offender Therapy \& Comparative Criminology, 51 (5), 495-509.

Ericson, N. (2001). Addressing the Problem of Juvenile Bullying Brochure. Retrieved from http://www.ncjrs.gov/pdffiles1/ojjdp/ fs200127.pdf

Espelage, D. \& Swearer, S. (2004). Bullying in American Schools. A social-ecological perspective on prevention and intervention. Mahwah: Erlbaum Associates.

Farrington, D. P. (2009). Conduct disorder, aggression and delinquency. In R. M. Lerner \& L. Steinberg (Eds.), Handbook of adolescent psychology (3rd ed., Vol. 1, pp. 683-722). Hoboken: Wiley

Farrington, D.P. \& Ttofi, M.M. (2011). Bullying as a predictor of offending, violence and later life outcomes. Criminal Behaviour and Mental Helth, 21, 90-98

Fisherman G,, Gustavo SM., Eisikovits Z. (2002). Variables affecting adolescent victimization: Finding from national Youth Survey. Western Criminology Review 3.

Fisherman. G., Gustavo, SM., Eisikovits. Z. (2002). Variables affecting adolescent victimization: Finding from national Youth Survey. Western Criminology Review 3. Retrieved from http;//wcr.soosma.edu/v3n2/fishman.html.

Fonagy, P., Twemlow, S. W., Vernberg, E., Sacco, F. C., \& Little, T. D. (2005). Creating a peaceful school learning environment: The impact of an antibullying program on educational attainment in elementary schools. Medical Science Monitor, 11, 317-325.

GINI, G., ROSSI, F., (2003), Quanto è grave la presenza del bullismo nella nostra scuola? Misure e strumenti per la valutazione. In: Menesini E. (a cura di), Bullismo: le azioni efficaci della scuola, Erickson, Trento

Goldbaum, S., Craig, W. M., Pepler, D. J., \& Connolly, J. (2003). Developmental Trajectories of Victimization: Identifying Risk and Protective Factors. Journal of Applied School Psychology, 19, 139-156.

Graham, S., Bellmore, A., \& Juvonen, J. (2003). Peer victimization in middle school: When self- and peer views diverge. Journal of Applied School Psychology, 19, 117-137

Hammig., B, \& Jozkowski., K. (2013). Academic achievement, violent victimization, and bullying among U.S. high school students. Family Studies Criminology \& Penology in Psychology Applied, 28(7):1424-36

Hong JS. (2009). Feasibility of the Olweus Bullying Prevention Program in low-income schools. Journal of School Violence. 8, 81-97.

Jensen JM, Dieterich WA. (2007). Effects of a skills-based prevention program on bullying and bully victimization among elementary school children. Prevention Science. 8, 285-296

Kanetsuna, T., \& Smith, P. K. (2002). Pupil insights into bullying, and coping with bullying: A binational study in Japan and England. Journal of School Violence, 1, 5-29.

Kevorkian, M., \& D'Antona, R. (2008). 101 facts about bullying: What everyone should know. Lanham, MD: Rowan \& Littlefield.

Ladd GW. (2003). Probing the adaptive significance of children's behavior and relationships in the school context: A child by environment perspective. Advances in Child Development. 2003;31:43-104. 
Luk JW, Wang J, Simons-Morton BG. (2010). Bullying victimization and substance use among U.S. adolescents: Mediation by depression. Prevention Science. 11, 355-359

Meyer-Adams, N., \& Conner, B. T. (2008). School violence: Bullying behaviors and the psychosocial school environment in middle schools. Children and Schools, 30, 211-221.

Monks CP, Smith PK, Naylor P, Barter C, Ireland JL, Coyne I. (2009). Bullying in different contexts: Commonalities, differences and the role of theory. Aggression and Violent Behavior. 14, 146-156

Nansel, T. R., Overpeck, M., Pilla, R. S., Ruan, W. J., Simons-Morton, B. G., \& Scheidt, P. (2001). Bullying behaviors among U.S. youth: Prevalence and association with psychosocial adjustment. Journal of the American Medical Association, 285, 2094-2100.

Olweus, D. (1973) 'Personality and aggression' in COLE, J. K. and JENSEN, D. D. (eds), Nebraska Symposium on Motivation 1972, Lincoln, University of Nebraska Press.

Olweus, D. (1978) Aggression in the schools: bullies and whipping boys, Washington DC, Hemisphere Press (Wiley).

Olweus, D. (1993). Bullying at school: What we know and what we can do. Oxford, UK: Blackwell.

Olweus, D. (2004). The Olweus Bullying Prevention Programme: Design and implementation issues and a new national initiative in Norway. In P. K. Smith, D. Pepler, \& K. Rigby (Eds.), Bullying in schools: How successful can interventions be? (pp. 13-36). Cambridge, UK: Cambridge University Press.

Pellegrini, A. D., \& Bartini, M. (2000). A longitudinal study of bullying, victimization, and peer affiliation during the transition from primary school to middle school. American Educational Research Journal, 37, 699-725.

Pepler, D.J., Smith, P.K., \& Rigby, K. (2004). Looking back and looking forward: Implications for making interventions work effectively. In P.K. Smith, D. Pepler, \& K. Rigby (Eds.), Bullying in schools: How successful can interventions be? (pp. 307-324). Cambridge, England: Cambridge University Press.

Rigby, K (2002). A meta-evaluation of methods and approaches to reducing bullying in pre-schools and in early primary school in Australia, Commonwealth Attorney-General's Department, Canberra.

Runions, K, C., Shaw, T. (2013) Teacher-child relationship, child withdrawal and aggression in the development of peer victimization. Journal of Applied Developmental Psychology 34 (2013) 319-327

Simmons, R. (2002). Odd girl out: The hidden culture of aggression in girls. NY: Harcourt.

Siris, K. \& Osterman, K. (2004). Phi Delta Kappan, 288-291.

Smith, P. K. (2011). Bullying in schools: Thirty years of research. In C. P. Monks, \& I. Coyne (Eds.), Bullying in different contexts (pp. 36-60). New York, NY: Cambridge University Press.

Smith, P.K. \& Shu, S. (2000). What good schools can do about bullying: Findings from a survey in English schools after a decade of research and action. Childhood, 7, 193-212.

Støm, I. F., Thoresen, S., Wentzel-Larsen, T., \& Dyb, G. (2013). Violence, bullying and academic achievement: A study of 15-year-old adolescents and their school environment.

Shin, Y., \& Kim, H. Y. (2008). Peer victimization in Korean preschool children: The effects of child characteristics, parenting behaviours and teacher-child relationships. School Psychology International, 29(5), 590-605.

Tamo, A., Karaj, Th. (2006), Dhuna ndaj fëmijëve në Shqipëri. Qendra e zhvillimeve humane Retrieved from: http://www.psikologjia.com/pdf/Dhuna_ndaj_femijeve_ne_Shqiperi.pdf

Troop-Gordon, W. \& Kuntz, K.J. (2013). The unique and interactive contributions of peer victimization and teacher-child relationships to children's school adjustment. Journal of Abnormal Child Psychology. doi:10.1007/s10802-013-9776-2

Ttofi, M. M., Farrington, D. P., Lösel, F., \& Loeber, R. (2011). The predictive efficiency of school bullying versus later offending: A systematic/meta-analytic review of longitudinal studies. Criminal Behaviour and Mental Health, 21, 80-89.

Thorbe, C. (2003). Bullying beliefs challenged Retrieved from http://www. shout.net/-rcs/eve/partch/handouts/bully.html.

Veenstra R, Lindenberg S, Oldehinkel AJ, De Winter AF, Verhulst FC, Ormel J (2005). Bullying and victimization in elementary schools : a comparison of bullies, victims, bully/victims, and uninvolved preadolescents. Developmental Psychology 41, 672-682.

Vieno., A, Gini., G, \& Santinello., M. (2011). Different forms of bullying and their association to smoking and drinking behavior in Italian adolescents. Journal of School Health, 81(7), 393-399.

Wienke Totura, C. M., MacKinnon-Lewis, C., Gesten, E. L., Gadd, R., Divine, K. P., Dunham, S., et al. (2008). Bullying and victimization among boys and girls in middle school. Journal of Early Adolescence, 29, 571-609.

Hay C, Meldrum R: (2010). Bullying victimization and adolescent self-harm: Testing hypotheses from general strain theory. $J$ Youth Adolesc, 39:446-459. 